\section{Ethical Lingua}

Journal of Language Teaching and Literature

ISSN 2355-3448 (Print)

ISSN 2540-9190 (Online)

Volume 5, Number 2, August 2018

pp. $159-170$

\title{
Intercultural Communication in EFL Classrooms
}

\author{
Markus Deli Girik Allo \\ jesuitzjoseph@yahoo.com
}

Universitas Kristen Indonesia Toraja, Indonesia

\author{
Received : 25 Juni 2018; Accepted: 25 July 2018 \\ URL : : http://journal.uncp.ac.id/index.php/ethicallingua/article/view/1036 \\ DOI : $\quad$ https://doi.org/10.30605/ethicallingua.v5i2.1036
}

\begin{abstract}
Intercultural communication is an important aspect in EFL classrooms since EFL classrooms are one of the learners' environments to learn the culture and intercultural communication. The researcher employed the quantitative research with survey design. This study investigated the place of culture and intercultural communication in Torajan EFL classrooms and Torajan students' perceptions on Imperatives for studying Intercultural Communication. It is found that: Students needed for the new cultural and intercultural knowledge in EFL classrooms and hoped that curriculum can meet their needs on intercultural communication competence, and students are aware and hope to institutional and EFL lecturers to create intercultural environment and encourage effective intercultural dialogue in EFL classrooms in order to achieve: pedagogical, personal development, peace, economic, demographic, and ethical imperatives of intercultural communication.
\end{abstract}

Keywords: intercultural communications; EFL classrooms 


\section{Introduction}

Culture is different things to different people. People from different culture differ in visible and invisible one. The visible different culture such as food, the way of clothing, language variety, and other ones. From the invisible one, culture different in belief, value, and norms. Padhi (2016) defines culture as the characteristics and knowledge of a particular group of people, represented by everything from language, religion, cuisine, social habits, music, and arts. It is crucial for people in their workplaces to be aware of the differences in communication. It is because most of the people in workplaces are diverse and need to be understood each other.

Each individual belongs to a special group. Every person characterized by different ways of thinking, behaviors, rituals, clothes, beliefs, values, and norms. $\mathrm{He} / \mathrm{she}$ can be easily differentiated from the other group of people (Mahadi, \& Jafari, 2012). Furthermore, Mahadi \& Jafari found that language and culture cannot be separated from each other. That is, Culture influences the language, and language is learned from generation to generation. Being sensitive to and understanding others' cultural productions and the way in which they play with the various identities available to them (discourses on their identities currently available in the context of their interactions) is a crucial part of good intercultural communication. A good interpersonal communicator, therefore, needs to be aware of issues surrounding the concept of identity. Before we can communicate with people who are different to ourselves, we need to understand something about how they present themselves as being or belonging to certain groups, (Holliday, Hyde, \& Kullman, 2004).

Basically, intercultural communication defines a situation of communication that occurred between two or more than that and those people differ in cultural background, (Issa, 2016). Intercultural communication is a symbolic, interpretive, transactional, contextual process in which people from different cultures create shared meanings. The situation around the world always changes every time. The people really pay attention to cultural issues. They began to be aware with the diversification among others and learn to understand the difference including of receiving it. This emphasis on culture is accompanied by numerous opportunities for experiences with people who come from vastly different cultural backgrounds. Intercultural encounters are now ubiquitous; they occur within neighborhoods, across national borders, in face-to-face interactions, through mediated channels, in business, in personal relationships, in tourist travel, and in politics. In virtually every facet of life-in work, play, entertainment, school, family, community, and even in the media that you encounter daily-your experiences necessarily involve intercultural communication, (Lustig, W., Myron, \& Koester, 2010). 
The changing global environment has influenced the increasing cultural diversity in many contexts (Martin et al. in Ayalew, Tsegaye, 2012). University campuses are no different in the attempt to create an intercultural environment for their own survival and effectiveness. For instance, academic discourse and pedagogical practices are improbable if an environment is not good enough to encourage effective intercultural dialogue among members. In other words, higher educational institutions should consider the growing demand for intercultural dialogue in their endeavors to respond to the needs of the community they host and meet institutional expectations. In line with these points and to be more specific, there are a number of imperatives for the study of intercultural communication in higher educational contexts (Ayalew, Tsegaye, 2012). As students, they will not only obtain the new knowledge about intercultural but more than that, they will get the chance to enlarge their relation with different people and will be easy to communicate with them. As result, in future, they will reduce culture shock if they make relation and communication in various cultures. Lustig, W., Myron, \& Koester (2010) stated that the need to understand the role of culture in interpersonal communication is growing. Because of demographic, technological, economic, peace, and interpersonal concerns, intercultural competence is now more vital than ever. Genc, \& Bada (2005) revealed that there is the difference between the students' thinking and some pertinent concepts of culture class advantageous.

Considering the advantages of participating in EFL classroom of learning a culture, the students can enhance their awareness of different culture both of their own culture and cross-culture. Farnia, Maryam, \& Rozina (2009) found that Cross-cultural and contrastive pragmatics studies help teachers with enhancing their students' awareness of the social and cultural differences of the native language and the language they are learning. Valencia, Álvarez, José Aldemar, \& Medina (2009) found that the teacher can improve their EFL teaching context through the enrichment bilaterally in the purpose of enhancing awareness of diversity in culture. Moreover, the students can increase their cultural sensitivity and competence in EFL learners. (Genc, Bilal, \& Bada, 2005) found out that the students agree on the importance of regarding the benefits of learning about the culture. Also, (Hui, 2010) revealed that attending the culture class has raised cultural awareness in ELT students concerning both native and target societies encouraging signs of teachers' and college trainers' willingness to engage in cultural teaching.

There is a very close relationship between language and culture, (Mahadi, Tengku, Sepora, Tengku, \& Jafari, Moghaddas, 2012). Teachers also should pay attention to textbook use in the purpose to meet the students' needs for intercultural knowledge. In term of textbooks content, (Girik Allo, 2018) found that the textbook does not meet the students' needs for Learning. It is suggested that the textbooks used in EFL teaching and learning should consider on 
students' need. When learning, students will gain recognize the imperatives of learning intercultural communication in EFL classrooms. The imperatives of intercultural communication in EFL classrooms stated by experts such as: (Ayalew, Tsegaye, 2012) stated that through the process of internationalization and diversity efforts, universities have been hosting culturally and the diverse linguistic group of students. For their own institutional and pedagogical orientations, campuses ought to consciously address the growing need for healthy and democratic interaction among students, staff, and leadership. Like as (Shemshadsara, 2012) found out that a shift from a traditional to intercultural stance in EFL helps to develop teachers' intercultural perspectives that may have an impact on their language teaching methodology and syllabus design. This shift is a challenge that EFL teachers and learners have to deal with to meet the goals of foreign language education in our modern world. It also influences the students' Personal development imperative. (Kastanakis \& Voyer, 2014) stated that people who experience conflict with the in-group must adhere to prescribed role expectations, act wisely and with maturity, and preserve "face". The effects of globalization on moving corporations abroad include marketing and economic reasons (Ayalew, Tsegaye, 2012). Moreover, Ayalew \& Tsegaye stated that Demographic imperatives: It is obvious that the world, its people, and societies are always in the state of change.

Through intercultural communication, we can learn more about other people and their unique cultures, and about ourselves culture as well as our background. At the same time, there will be challenges come as stereotypes and discriminations. But, through intercultural communication competence, we can communicate well with other people wherever we are and in every context of communication. Chi (2016) found that the challenges people from both cultures faced while working with others. The challenges included different working styles, different level of language, and usage of non-verbal communication. It is significant of being a good listener and doing the observation to other cultures while having communication and relation with different people in the different culture. In observing others, a person will identify the similarities and differences. That is all as the foundation to gain an effective communication across culture. The advantage intercultural communication also appeared in the business field that "It is imperative for the business firms to understand the cross-cultural differences in their operations and this understanding acquires more importance in the sphere of communicating with people hailing from diverse cultures. Hence a Multinational Company (MNC) will have to ensure that steps are taken to overcome the barriers to cross cultural communication to attain organizational objectives effectively and efficiently", (Padhi, 2016).

In the context of Torajan Students, Especially in English Education Program study, they are like other Indonesian students in general, learning English through the amount of Courses. They are learning: English skills, and Language 
elements, and overall, they could show good achievement. It was shown by 3.00 GPA of all graduation in 2018 in the odd semester. The data from Speaking Lecturers also showed that the students could pass the course well and of all students who programmed that course only $5 \%$ from 205 students that got grade " $C$ " and the others were above grade "B". Writing course's lecturers also stated that the students have a good critical thinking and good motivation in learning. From the final grade, only $7 \%$ from 193 students who joined that course that got " $C$ ' score, other ones could pass this course by getting "A", and "B" grade. Then, the writer did the observation to the students in their classroom activities and intercultural communication. In EFL learning and Teaching, when they learn about the topics such worldwide geography from literary works, a story from overseas, tuitions, rituals, belief, norms, and values overseas they were confused and difficult to understand the new terms.

Other cases, Universitas Kristen Indonesia (UKI) Toraja on several occasions got chance to collaborate with Australian students in Education Program by living in Torajan societies for several weeks. The challenges appeared mainly in intercultural communication. Australian students assumed that they were difficult to communicate with the Torajan students because of misunderstanding both of verbal and non-verbal language. Torajan students said that they mainly used indirect language and Australian students more direct in communication. Torajan students also said that there are many idioms and figurative language used by Australian students that difficult to understand by Torajan students. Moreover, considering to UKI Toraja syllabus, it showed that the contextual EFL teaching as a factor of limited in formations and knowledge of intercultural communication of the students. The lecturer, based on the interview, rarely taught intercultural communication while teaching. It is because they are a focus to finish the material based on curriculum exists in UKI Toraja. From the problem above, the researcher formulates the research questions as: 1) What is the place of culture and intercultural communication in Torajan EFL Classrooms? and 2) What are Torajan Students perceptions on Imperatives for Studying Intercultural Communication? From that research questions, this research aims to reveal the place of culture and intercultural communication in Torajan EFL classrooms, and Torajan students' perceptions on imperatives for studying intercultural communication.

Investigation on intercultural communication in EFL classrooms is very significant to contribute useful instructional material for Cross-Cultural Understanding Course. For that reason, the lecturers will consider reconstructing their curriculum to fill the intercultural communication in the syllabus to enlarge the students' insight of intercultural communication. Therefore, someday, the students will have a good awareness of the diversities of culture as the way to gain an effective communication wherever they are. 


\section{Method}

The researcher in this study employed the quantitative research with survey design. Survey design as (Antonius, 2003) said that Surveys consist in asking a large number of people some specific questions, or in collecting data about a large number of statistical units. Surveys consist in asking a large number of people some specific questions, or in collecting data about a large number of statistical units. In conducting a survey, the researcher constructs a questionnaire (that is, a list of all the questions for which a researcher are seeking answers), the researcher determines the sample or population on which she/he wants to conduct it, then fills out the questionnaires either by direct interviews or by asking people in sample to fill the questionnaires themselves, or by consulting some appropriate archive.

The respondents in this research are the voluntary respondents that consisted of 207 students of even semester, academic year 2017/2018 of English Study Program, FKIP UKI Toraja. The data about the place of culture and intercultural communication in Torajan EFL learners and Torajan students' perceptions on Imperatives for Studying Intercultural Communication were collected through a questionnaire. This questionnaire is an attitude scale which was developed by (Hui, 2010) but it is modified by the researcher to suit the requirements of the topic of the research. The questionnaire used five points of the Likert scale, they are: strongly disagree (1 point), disagree (2 points), undecided (3 points), agree (4 points) or strongly agree (5 points). After distributing the instrument of the questionnaire to the students, the writer collected and analyzed through percentage and frequency. Then, the writer ranked the students' response based on the level of agreement.

\section{Results}

The Place of Culture and Intercultural Communication in Torajan EFL Classrooms

Table 1. Percentages (\%) on the place of culture and intercultural competence

\begin{tabular}{llll}
\hline \multicolumn{1}{c}{ Items of section 1 } & Agreement (\%) & Disagreement (\%) \\
\hline 1 & $\begin{array}{l}\text { In a foreign language classroom, teaching } \\
\text { culture is as important as language teaching. }\end{array}$ & 165, or $79,71 \%$ & 42, or $20,29 \%$ \\
2 & $\begin{array}{l}\text { Before Learning L2 culture, students have to } \\
\text { possess a sufficiently high level of L2 } \\
\text { proficiency. }\end{array}$ & 139, or $67,14 \%$ & 68 or $32,86 \%$ \\
3 & $\begin{array}{l}\text { Language \& culture cannot be learned in an } \\
\text { integrated way; you have to separate the two. }\end{array}$ & 70 or $33,81 \%$ & 137 or $66,19 \%$ \\
\hline
\end{tabular}




\begin{tabular}{llll}
\hline \multicolumn{1}{c}{ Items of section 1 } & Agreement (\%) & Disagreement (\%) \\
\hline 4 & $\begin{array}{l}\text { It is impossible to learn L2 culture \& L2 } \\
\text { language in an integrated way. }\end{array}$ & 87 or $42,02 \%$ & 120 or $57,98 \%$ \\
5 & $\begin{array}{l}\text { The cultural contents of the textbooks used in } \\
\text { the department meet my expectations. }\end{array}$ & 61 or $29,46 \%$ & 146 or $70,54 \%$ \\
6 & $\begin{array}{l}\text { Intercultural competence cannot be acquired } \\
\text { at school. }\end{array}$ & 17 or $31,19 \%$ & 130 or $62,81 \%$ \\
7 & $\begin{array}{l}\text { L2 Culture teaching does not improve } \\
\text { intercultural competence; it is waste of time. }\end{array}$ & 41 or $19,80 \%$ & 166 or $80,20 \%$ \\
\hline
\end{tabular}

From the data above, students believe that teaching culture is similar importance with language teaching, both of them are needed by students in EFL classrooms (item 1), they think that they have to understand L2 proficiency before learning L2 Culture (item 2). Students assume that they need to learn language and culture in a separated way (item 3 ), and they think that in learning L2 culture \& L2 language also should be in the separated way (item 4). In item 5, the textbook used in their department does not meet their needs of L2 culture and language. Students believe that they can acquire Intercultural competence at school (item 6). They also think that L2 Culture teaching improves the intercultural competence of the students (item 7).

\section{Torajan Students Perceptions on Imperatives for Studying Intercultural Communication}

Table 2. Percentages (\%) on students' perceptions on imperatives for studying intercultural communication

\begin{tabular}{llll}
\hline & Items of section 2 & Agreement (\%) & Disagreement (\%) \\
\hline 8 & $\begin{array}{l}\text { Universities should demonstrate superiority } \\
\text { in intercultural organizational behavior and } \\
\text { intercultural management skills to their } \\
\text { students. }\end{array}$ & & \\
\hline 9 & $\begin{array}{l}\text { Multicultural policies and curricula should be } 85,02 \% \\
\text { revised to embrace the need for intercultural } 14,98 \%\end{array}$ & \\
& $\begin{array}{l}\text { interactions besides attempts to represent } \\
\text { diverse cultural values and dimensions. }\end{array}$ & & \\
\hline 10 & $\begin{array}{l}\text { Acquisition of intercultural competence \& } \\
\text { experiencing intercultural communication } \\
\text { are imperatives for personal benefits of the }\end{array}$ & & \\
& & & \\
youth & & & \\
\hline
\end{tabular}




\begin{tabular}{|c|c|c|c|}
\hline & Items of section 2 & Agreement (\%) & Disagreement (\%) \\
\hline 11 & $\begin{array}{l}\text { Through intercultural training and } \\
\text { experience, students can contribute to the } \\
\text { efforts of combating intercultural/interethnic } \\
\text { conflicts which are fueled as a result of } \\
\text { cultural, political, economic or other reasons. }\end{array}$ & 108 or 52,17 & 99 or $47,83 \%$ \\
\hline 12 & $\begin{array}{l}\text { As globalization presents multicultural } \\
\text { corporations and the creation of a world } \\
\text { market, higher educational institutions } \\
\text { should not offer intercultural communication } \\
\text { courses and experiences to their students }\end{array}$ & 61 or $29,46 \%$ & 146 or $70,54 \%$ \\
\hline 13 & $\begin{array}{l}\text { The changing demography does not require } \\
\text { universities to react to this imperative by } \\
\text { providing such experiences and skills to their } \\
\text { students. }\end{array}$ & 78 or $37,68 \%$ & 129 or $62,32 \%$ \\
\hline 14 & $\begin{array}{l}\text { Academia should not teach ethical issues } \\
\text { such as respect for basic human and } \\
\text { democratic right; value cultural diversity and } \\
\text { credit social justice and merits of intercultural } \\
\text { dialogue. }\end{array}$ & 35 or $16,90 \%$ & 172 or $83,10 \%$ \\
\hline
\end{tabular}

The second research question is about "What are Torajan Students perceptions on Imperatives for Studying Intercultural Communication?" Students believe that Universities should demonstrate superiority in intercultural organizational behavior and intercultural management skills to their students (item 8). The students think that multicultural policies and curricula should be revised to embrace the need for intercultural interactions besides attempts to represent diverse cultural values and dimensions (item 9). They assume that acquisition of intercultural competence and experiencing intercultural communication are imperatives for personal benefits of the youth (item 10). Students think that through intercultural training and experience, students can contribute to the efforts of combating intercultural/interethnic conflicts which are fueled as a result of cultural, political, economic or other reasons (item 11). Students assume that as globalization presents multicultural corporations and the creation of a world market, higher educational institutions should offer intercultural communication courses and experiences to their students (item 12). Students believe that the changing demography requires universities to react to this imperative by providing such experiences and skills to their students (item 13). Students think that academia should teach ethical issues such as respect for basic human and democratic right; value cultural diversity and credit social justice and merits of intercultural dialogue (item 14). 


\section{Discussion}

The present study aims to reveal the place of culture and intercultural competence in Torajan EFL learners, and Torajan students' perceptions on Imperatives for Studying Intercultural Communication. The result of the study is expected to contribute useful instructional material for Cross-Cultural Understanding Course. Also, by revealing the place of culture and intercultural competence in Torajan EFL learners, and students' perceptions on imperatives for studying intercultural communication, the lecturers will consider to reconstructing their curriculum to fill the intercultural communication in the syllabus in order to enlarge the students' insight of intercultural communication.

\section{The Place of Culture and Intercultural Communication in Torajan EFL Classrooms}

By comparing with the previous studies, the present study shows the similarity they are (Genc, Bilal, \& Bada, 2005) found out that the students agree on the importance of regarding the benefits of learning about the culture. Also, (Hui, 2010) revealed that attending the culture class has raised cultural awareness in ELT students concerning both native and target societies encouraging signs of teachers' and college trainers' willingness to engage in cultural teaching. The present study revealed that students believe that teaching culture is of similar importance to the language teaching, both of them are needed by students in EFL classrooms. In the term of learning L2 Culture and language, the students think that they have to learn language and culture in a separated way. It is different with the finding in the research conducted by (Mahadi, Tengku, Sepora, Tengku, \& Jafari, Moghaddas, 2012) that there is a very close relationship between language and culture. That is, culture has a direct effect on language. Language and culture are closely correlated. Also different with the finding of the research by (Hui, 2010) that Teachers are sure to have got some understanding of the integration of language teaching with cultural teaching and gradually realized the importance of raising students' cultural awareness in language teaching.

In term of textbooks content, the students think that the textbook used do not meet the students' needs/ expectations. It is similar to the research by (Girik Allo, 2018) that the textbook does not meet the students' needs in Learning. It is suggested that the textbooks used in EFL teaching and learning should consider on students' need. In this research, the students believe that Intercultural competence can be acquired at school. It is similar to the finding in the research done by (Shibata, 1998) that Intercultural Communication training is a necessity for students to achieve intercultural competence. Through an IC course, students should gain self-awareness, and culture-general knowledge, and learn skills that will help them to communicate effectively with persons from other cultures. It is 
also similar to the finding in this present study that the students think that L2 Culture teaching can improve the intercultural competence of the students.

\section{Torajan Students perceptions on Imperatives for Studying Intercultural Communication}

In the second objective of the study of revealing Torajan Students perceptions on Imperatives for Studying Intercultural Communication, the researcher also compared with the finding of others and some pertinent concepts in this article. (Ayalew, Tsegaye, 2012) state that through the process of internationalization and diversity efforts, universities have been hosting culturally and the diverse linguistic group of students. For their own institutional and pedagogical orientations, campuses ought to consciously address the growing need for healthy and democratic interaction among students, staff, and leadership. Institutional effectiveness is hardly possible without dealing with the needs of the workforce.

The finding of this study shows the similarity that the students think about institutional imperative, Universities should demonstrate superiority in intercultural organizational behavior and intercultural management skills to their students. Dealing with the Pedagogical imperative, the students think that multicultural policies and curricula should be revised to embrace the need for intercultural interactions besides attempts to represent diverse cultural values and dimensions. Like as (Shemshadsara, 2012) found out that a shift from a traditional to intercultural stance in EFL helps to develop teachers' intercultural perspectives that may have an impact on their language teaching methodology and syllabus design. This shift is a challenge that EFL teachers and learners have to deal with to meet the goals of foreign language education in our modern world. It also influences the students' Personal development imperative. It can be seen in this research that the students believe that acquisition of intercultural competence and experiencing intercultural communication are imperatives for personal benefits of the youth.

For Peace imperative, students think that through intercultural training and experience, students can contribute to the efforts of combating intercultural/interethnic conflicts which are fueled as a result of cultural, political, economic or other reasons. As (Kastanakis \& Voyer, 2014) stated that people who experience conflict with the in-group must adhere to prescribed role expectations, act wisely and with maturity, and preserve "face". The effects of globalization on moving corporations abroad include marketing and economic reasons (Ayalew, Tsegaye, 2012). Moreover, Ayalew \& Tsegaye stated that Demographic imperatives: It is obvious that the world, its people, and societies are always in the state of change. The social landscapes in Europe, the US and other parts of the world have increasingly been diverse. For example, in once only white dominated small and cold town in Norway, it is not any more unusual to 
encounter people from various parts of the world. Then, every culture offers an established set of cultural values, ethical judgments, cultural patterns, norms, and worldview.

The established set of good and bad behaviors could be stated explicitly or implicitly and shared among members of the same culture. In this study, students hope that higher educational institutions should offer intercultural communication courses and experiences to their students the students believe that on item demographic imperative, students believe that the changing demography requires universities to react to this imperative by providing such experiences and skills to their students. For item ethical imperatives, students think that academia should teach ethical issues such as respect for basic human and democratic right; value cultural diversity and credit social justice and merits of intercultural dialogue.

\section{Conclusion}

This study investigated the place of culture and intercultural communication in Torajan EFL classrooms, and Torajan students' perceptions on imperatives for studying intercultural communication. It is found that: Students needed for the new cultural and intercultural knowledge in EFL Classrooms, and hoped that curriculum can meet their needs on Intercultural Communication competence, and Students are aware and hope to Institutional and EFL Lecturers to create intercultural environment and encourage effective intercultural dialogue in EFL classrooms in order to achieve: pedagogical, personal development, peace, economic, demographic, and ethical imperatives of intercultural communication.

Successful culture and intercultural EFL classrooms determined by consciously address the growing need for healthy and democratic interaction among students. Therefore, institution, especially English Department needs to consider on revising the EFL curriculum in order to meet the students need on cultural and intercultural competence.

\section{References}

Antonius, R. (2003). Interpreting Quantitative Data with SPSS. London: SAGE Publications Ltd.

Ayalew, T. A. (2012). An Integrative Approach to Intercultural Communication in Context: Empirical Evidences from Higher Education. University Giessen.

Chi, D. L. (2016). Intercultural Communication: Differences between Western and Asian Perspective. Centria University of Applied Sciences.

Farnia, M., \& Rozina, R. (2009). Contrastive pragmatic study and teaching culture in English language classroom - A case study. https://www.researchgate.net/publication/213917404_Contrastive_pragmatic_stu dy_and_teaching_culture_in_English_language_classroom-_a_case_study 
Girik Allo:

Intercultural Communication in EFL Classrooms

Genc, B., \& Bada, E. (2005). Culture in language learning and teaching. The Reading Matrix, 5(1), 73-84.

Girik Allo, M. D. (2018). An Evaluative study on Prose Textbook (EFL Curriculum and Need Analysis). In The International Conference on Social Sciences and Humanities (pp. 519-524). Johor Baru, Malaysia: Faculty of Management.

Holliday, A., Hyde, M., \& Kullman, J. (2004). Intercultural Communication: An Advanced Resource Book. (R. Candlin, N. Christopher, and Carter, Ed.). London, and New York: Taylor \& Francis e-Library.

Hui, H. (2010). An Investigation of Teachers' Perceptions of Culture Teaching in Secondary Schools in Xinjiang, China. University of Durham, School of Education University of Durham U.K.

Issa, A. A. (2016). The Meaning and Theories of Intercultural Communication. https://doi.org/10.13140/RG.2.2.14026.36806

Kastanakis, M. N., \& Voyer, B. G. (2014). The effect of culture on perception and cognition : a conceptual framework. Journal of Business Research, 67(4), 1-38. https://doi.org/10.1016/j.jbusres.2013.03.028

Lustig, W., Myron, \& Koester, J. (2010). Intercultural Competence: Interpersonal Communication across Cultures. (K. Bowers, Ed.) (6th Ed.). United States: Pearson.

Mahadi, T., Sepora, T., \& Jafari, S. M. (2012). Language and Culture. International Journal of Humanities and Social Science, 2(17), 230-235.

Padhi, P. K. (2016). The Rising Importance of Cross Cultural Communication in Global Business Scenario, 4(1), 20-26.

Shemshadsara, Z. G. (2012). Developing Cultural Awareness in Foreign Language Teaching. English Language Teaching, 5(3), 95-99. https://doi.org/10.5539/elt.v5n3p95

Shibata, A. M. (1998). Intercultural Communication Concepts and Implications for Teachers. JALT Journal, 20(2), 104-118.

Valencia, Á., Aldemar, J. \& Medina, X. B. (2009). Addressing Culture in the EFL Classroom : A Dialogic Proposal. Departamento de Lenguas Extranjeras. Bogotá, Colombia, 11(59), 151-170. 